- Information from PDPs developed by dentists can be used to develop courses and educational resources for the GDP community.

- Use of hands-on workshop format in small practice groups to develop significant event data.

- The introduction of Significant Event Analysis as a practice management tool can help with the smooth running of a practice.

- Production and distribution of a significant events library is a useful resource for dentists.

- Forty-five percent of Sheffield GDPs now have written PDPs against a 16\% national average.

\title{
The use of significant event analysis and personal development plans in developing CPD: a pilot study
}

\author{
P. D. Wright ${ }^{1}$ and C. D. Franklin ${ }^{2}$
}

This paper describes the work undertaken by the Postgraduate Primary Care Trust (PCT) Dental Tutor for South Yorkshire and East Midlands Regional Postgraduate Dental Education Office during the first year of a two-year pilot. The tutor has special responsibility for facilitating the writing of Personal Development Plans (PDPs) and the introduction of Significant Event Analysis to the 202 general dental practitioners in the four Sheffield PCTs. Data were collected on significant events and the educational needs highlighted as a result. A hands-on workshop format was used in small practice groups and $45 \%$ of Sheffield general dental practitioners now have written PDPs compared with a 16\% national average. A library of significant events has also been collated from the data collected.

\section{INTRODUCTION}

The position of Postgraduate PCT Dental Tutor (referred to in this paper as the tutor) was set up as a two-year pilot by the South Yorkshire and East Midlands Regional Postgraduate Dental Education Office, in order to promote the use of Personal Development Plans (PDPs) in primary dental care. The tutor was given special responsibility for developing PDPs and significant event analysis (SEA) for general dental practitioners (GDPs) in the four Sheffield PCTs.

The aims were:

- to visit as many GDPs as possible in the area and facilitate the development of a PDP for each practitioner

- to introduce practitioners to SEA

\footnotetext{
1,2*South Yorkshire and East Midlands Regional Postgraduate Dental Education Office, Don Valley House Savile Street East, Sheffield, S4 7U0

*Correspondence to: Professor Christopher Franklin Email: c.franklin@sheffield.ac.uk
}

\section{Refereed Paper}

Accepted 3 August 2006

DOI: $10.1038 /$ bdj.2007.586

${ }^{\circledR}$ British Dental Journal 2007; 203: 43-47
- to collect data on the educational needs highlighted by the PDPs

- to collect examples of significant events (SEs) that had occurred in practice.

The purpose of Personal Development Plans Having an up to date PDP demonstrates a professional approach to continuing professional development (CPD); it is a mechanism by which educational needs are identified, prioritised and commitments made to address them. ${ }^{1}$ Current GDC regulations require each dentist to complete on average 15 hours of verifiable CPD and 35 hours of non-verifiable CPD each year over a five year cycle. ${ }^{2}$ Not all of this CPD needs to be included in the PDP. A PDP should promote reflection on personal educational needs and lead to the selection of educational resources to meet those needs. This should in turn increase the impact of CPD on clinical practice and patients. $^{3}$

Each plan is personal and helps to direct an individual's learning, specifically in relation to professional development. Ideally, a written evaluation of learning is kept in a portfolio; the collection of this evidence should be helpful with future revalidation. GDPs should aim to use successful learning methods in their PDPs as they may suit their learning style. ${ }^{4}$

\section{An introduction to Significant}

Event Analysis

Significant events are those events that have an impact upon us. They can be events that go well or those that go wrong and may be linked to failed processes. $^{5}$ The aim of SEA is to reflect on and learn from these events, to prevent mistakes from happening again and to ensure that the things that work well continue to work well or are even improved upon, so as to improve the quality of patient care.

As they are significant, ie they make an impact, they can be powerful motivators for change. SEA helps to harness and focus this power. Pringle stated that, 'significant events, because they are de facto emotionally charged and compel 


\begin{tabular}{|c|c|c|c|}
\hline GDP & Educational needs & Activities required & Course codes \\
\hline $\operatorname{Dr} A$ & $\begin{array}{l}\text { Ceramic Restorations, Basic } \\
\text { Computer skills, Decide on future } \\
\text { within NHS }\end{array}$ & $\begin{array}{l}\text { Restorations - Laboratory } \\
\text { visit and discussion with } \\
\text { technicians. } \\
\text { Undertake basic computer } \\
\text { course, Peer discussion and } \\
\text { PCT input re: } 2005 \text { changes }\end{array}$ & $\begin{array}{l}\text { Restorations } \\
\text { Computer skills } \\
\text { Future of NHS }\end{array}$ \\
\hline $\operatorname{Dr} B$ & $\begin{array}{l}\text { Smoking cessation - pharmacol- } \\
\text { ogy }\end{array}$ & $\begin{array}{l}\text { Produce criteria to target } \\
\text { compliant patients, shadow } \\
\text { medical practice nurse with } \\
\text { experience with smoking } \\
\text { cessation. Use an audit of } 100 \\
\text { pts to gauge effectiveness of } \\
\text { chosen methods. Attend PG } \\
\text { courses in Barnsley. }\end{array}$ & Pharmacology \\
\hline $\operatorname{DrC}$ & $\begin{array}{l}\text { Dentures, Dealing with difficult } \\
\text { patients, MFGDP, Molar Endo- } \\
\text { dontics }\end{array}$ & $\begin{array}{l}\text { Courses, Reading material, } \\
\text { Internet, for endo - practice } \\
\text { on extracted teeth, buy new } \\
\text { technology }\end{array}$ & $\begin{array}{l}\text { Dentures } \\
\text { Communication } \\
\text { skills Diploma } \\
\text { training } \\
\text { Endodontics }\end{array}$ \\
\hline
\end{tabular}

Table 2 Examples of three reported significant events

\begin{tabular}{|c|c|c|}
\hline Significant event & $\begin{array}{l}\text { Changes made to clinical/ } \\
\text { administrative practices }\end{array}$ & Educational needs highlighted \\
\hline $\begin{array}{l}\text { Patient who suffered from } \\
\text { asthma arrived for extraction. } \\
\text { Patient very out of breath after } \\
\text { climbing stairs to surgery. Tooth } \\
\text { was extracted after patient } \\
\text { regained composure. The patient } \\
\text { collapsed, post extraction. Oxy- } \\
\text { gen given and ambulance called. }\end{array}$ & $\begin{array}{l}\text { Emergency procedures } \\
\text { implemented at the practice } \\
\text { worked well but protocols were } \\
\text { investigated to ensure that they } \\
\text { were still best practice. Patients } \\
\text { with cardio/respiratory history } \\
\text { should be treated in ground } \\
\text { floor surgery whenever possible. } \\
\text { Investigate installation } \\
\text { of chairlift. }\end{array}$ & $\begin{array}{l}\text { Update to CPR and emergency } \\
\text { procedures to reinforce } \\
\text { good practice }\end{array}$ \\
\hline $\begin{array}{l}\text { A patient who required antibiotic } \\
\text { cover for his dental treatment } \\
\text { had an anaphylactic response } \\
\text { to the amoxicillin he had been } \\
\text { given to take. The incident } \\
\text { occurred at the patient's home } \\
\text { and the patient's wife was able } \\
\text { to call an ambulance. The patient } \\
\text { was given emergency treat- } \\
\text { ment by the paramedics and } \\
\text { immediately taken to hospital. } \\
\text { He recovered fully. This patient } \\
\text { had been prescribed amoxicillin } \\
\text { twice before with no reaction. }\end{array}$ & $\begin{array}{l}\text { Patients' notes were altered so } \\
\text { that a different antibiotic regime } \\
\text { would be used in the future. } \\
\text { The incident was discussed at } \\
\text { the practice and it was decided } \\
\text { that all antibiotic cover patients } \\
\text { should be advised to take their } \\
\text { antibiotics with another adult } \\
\text { present or they should take } \\
\text { them while at the practice. }\end{array}$ & $\begin{array}{l}\text { Need to take the opportunity } \\
\text { to investigate best practice } \\
\text { in antibiotic prescribing } \\
\text { and prophylaxis. }\end{array}$ \\
\hline $\begin{array}{l}\text { Paraesthesia (temporary). } \\
\text { Caused by the use of Articaine } \\
\text { when giving ID block. }\end{array}$ & $\begin{array}{l}\text { Discussion with colleagues led } \\
\text { to conclusion that this was } \\
\text { relatively common occurrence. } \\
\text { Stopped using Articaine for } \\
\text { ID blocks. }\end{array}$ & $\begin{array}{l}\text { Articaine should not be used for } \\
\text { ID blocks. All GDPs should be } \\
\text { made aware of this. }\end{array}$ \\
\hline
\end{tabular}

one to take stock, may be powerful motivators to change behaviour providing that the potential for them to provoke a barrier of defensiveness is removed. ${ }^{6}$ Pringle also says that SEA has a power that is out of all proportion to the work involved and has the potential to produce real change in the practice. care dental practice and to see how CPD could be developed from knowledge of these events.

\section{METHOD}

Introduction of the project to practices

It was decided to focus the project on GDPs in primary care, excluding vocational trainees, community and hospital dentists, as these groups have their own well-established support structures.

A personalised letter of introduction from the PCT Tutor was sent to all Sheffield GDPs; it also included an invitation to request a visit from the tutor. All replies were followed up with a telephone call. This gave the opportunity for the tutor to further explain the importance of PDPs and the tutor's role in their development. The tutor also made an offer of a practice visit. The visit would include a workshop session on how to write a PDP, allow time for the GDP to write their own PDP and also give them an introduction to SEA. Each respondent was asked to invite all the dentists in the practice to this meeting, even if they had not personally responded to the initial letter of introduction. This approach helped to increase the uptake of PDPs above the original response rate. Prior to the practice visit, two single page questionnaires were sent to each GDP. Each questionnaire comprised no more than seven questions, to determine each practitioner's prior knowledge about PDPs and SEAs. These questionnaires used a combination of tick boxes and additional boxes for free text comments. In order to provide educational support for this work, every dental practice in Sheffield was provided with a copy of the textbook Personal Development Plans for dentists. ${ }^{1}$

\section{Practice visits}

The initial respondents were visited at their practices within the first six to nine months. It was then decided to focus on specific groups of dentist (see below). It was decided to limit the practice visit to 1.5 hours so that it could fit in to an extended lunch break or early evening meeting. A PowerPoint presentation was developed that gave enough time for an initial explanation of PDPs and their place in practice; time was also allowed for reflection on educational needs and discussion of how to write and complete a PDP. The presentation 
also included an introduction to SEA and enough time was set aside to collect examples of significant events from the attending GDPs.

The paperwork used in the practice visits was taken from Personal Development Plans for dentists. ${ }^{1}$ The forms can be downloaded from the publisher's website at www.radcliffe-oxford.com/ pdpdentists. ${ }^{9}$

After each practice visit, a short report was written with the names of the GDPs present and the educational needs highlighted by their PDP. A significant event was also collected from each GDP.

\section{Single-handed dentists}

Single-handed dentists do not have a peer structure within their own practice; therefore, some can become professionally isolated and struggle to implement clinical governance principles. For these reasons, it was decided to follow up all single-handed dentists, in the four Sheffield PCTs, who had not already requested a practice visit. A further letter was sent to try and engage this group of dentists and, as replies were received from these GDPs, practice visits were arranged.

\section{Dentists with low CPD}

From records of attendance at CPD events held in the Postgraduate Dental Education Office, it was possible to produce a list of every Sheffield GDP showing the number of CPD hours recorded for each one (Only MADEL funded courses organised in the South Yorkshire and East Midlands Postgraduate Office region are recorded. MADEL funded courses attended outside the region and privately funded courses attended are not recorded).

Three groups of GDPs were identified dependent on the date of their registration with the GDC and therefore the date on which their five-year CPD cycle ends. $^{3}$

A letter was sent to all dentists likely to be reviewed in 2007 who had less than 35 hours' CPD recorded. These dentists are required to complete 75 hours' verifiable CPD by 31 December 2006. It was decided to target those dentists who had less than half the required CPD recorded by the postgraduate office. The letter explained the five-year CPD cycle and the financial benefits (at that time) of the Continuing Professional Development Allowance (CPDA). The GDPs were

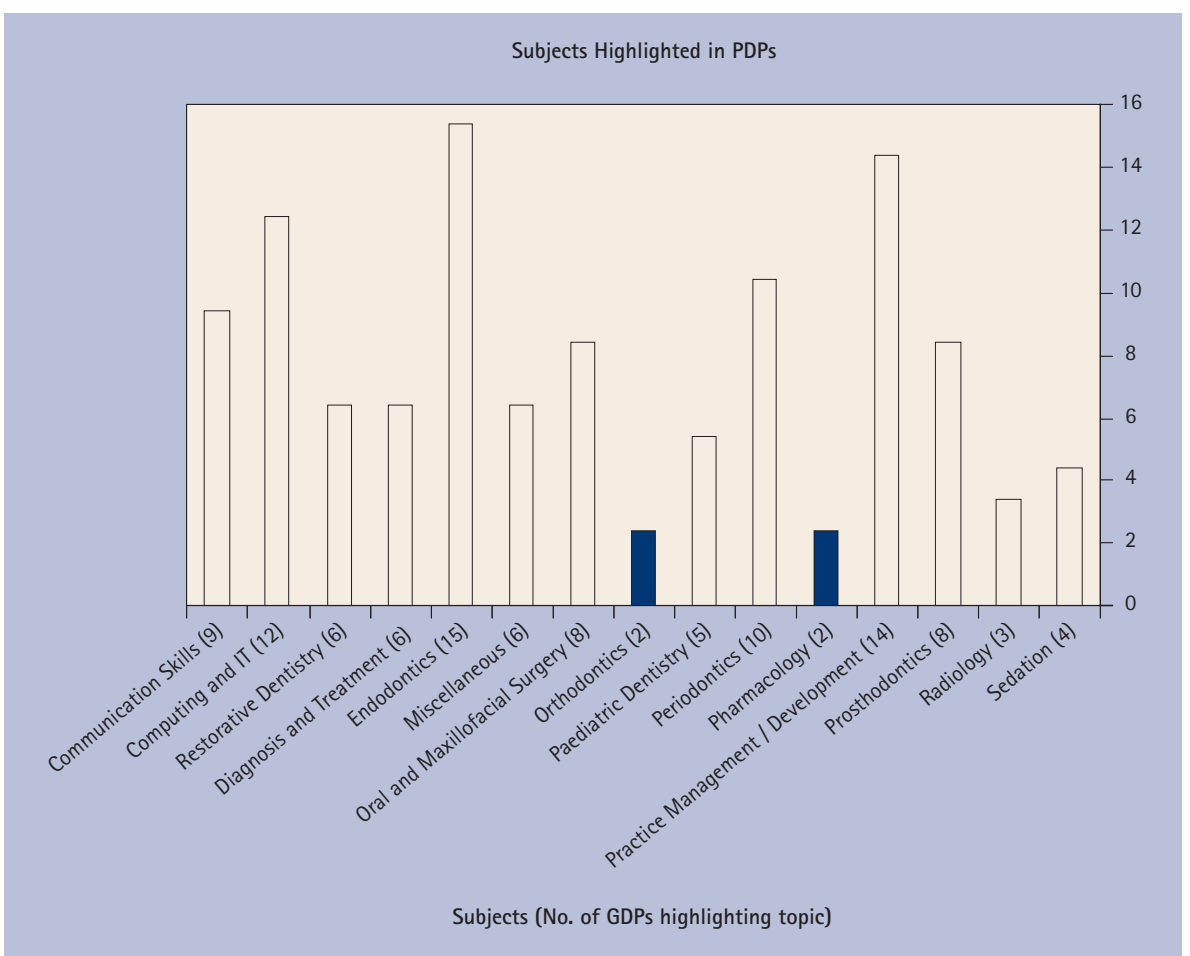

Fig. 1 Range of educational needs identified from collective PDP

invited to contact the tutor to arrange a practice visit at which a PDP could be developed that would help the practitioner to meet the GDC requirements for CPD.

\section{RESULTS}

\section{Personal Development Plans}

The initial response to the first mail shot was poor with 37 replies received from 202 letters sent out (18.32\%). The inclusion of respondents' colleagues increased the number of GDPs involved to $75(37.13 \%)$. From the pre-visit questionnaires it became apparent that only a small number of dentists had an up to date written PDP.

Of the 202 Sheffield GDPs, 91 (45\%) had been visited by the end of the first year, all of whom have completed their own written PDP. This compares with the GDC reported national average of dentists with a written PDP at $16 \% .^{10}$

All the educational needs highlighted by the practitioners were collected and logged on the Deanery database. This was not in an anonymous format as it was important to link the educational needs to practitioners. Table 1 shows examples of the data entered into the database for three practitioners. The range of educational needs highlighted is shown in Figure 1. The most common areas of need were endodontics (15), practice management and development
(14) and computing and IT skills (12). Ten dentists identified periodontology as an area of need.

In Sheffield, 20 single-handed practitioners were identified; of these, 12 $(60 \%)$ were visited. The educational needs highlighted by these dentists had a bias towards non-clinical, practice management topics with four practitioners highlighting computing and IT skills, and three highlighting practice management topics. The most common clinical topic was endodontics; three practitioners highlighted this.

The response rate from the targeted letters to the dentists with low CPD was very poor with only a handful of replies. A number of GDPs with low CPD had in fact accumulated verifiable CPD outside the deanery area; this was therefore not recorded on our database.

\section{Significant Event Analysis}

From the original 75 questionnaires circulated to those who responded to the first telephone call, only 28 (37.3\%) SEA questionnaires were returned, 12 were either blank or showed that the respondent did not understand what SEA was. Over the first year, 100 anonymised significant events have been collected and logged. These events have been collected primarily at practice meetings but also at workshops or lectures. All the events collected have been collated into 
Table 3 Example of completed significant event reporting form

\begin{tabular}{|c|c|}
\hline Reflection & \\
\hline $\begin{array}{l}\text { 1. Description } \\
\text { of event }\end{array}$ & $\begin{array}{l}\text { A patient attended the practice with a fractured cusp on an upper premolar. She } \\
\text { was seen as an emergency and a glass ionomer filling was used to temporary dress } \\
\text { the tooth. The patient complained when she found that the next available appoint- } \\
\text { ment for the permanent restoration was in six weeks. She was going on holiday in } \\
\text { two weeks and was concerned that the temporary dressing might give problems } \\
\text { whilst she was away. }\end{array}$ \\
\hline $\begin{array}{l}\text { 2. Issues raised } \\
\text { by event }\end{array}$ & $\begin{array}{l}\text { Since the move of the practice to PDS the waiting list had started to grow as more } \\
\text { time was being allocated for NICE guideline oral assessments and individual treat- } \\
\text { ments. Although emergency slots were provided each day, any follow up appoint- } \\
\text { ments were several weeks away. }\end{array}$ \\
\hline 3. What went well? & $\begin{array}{l}\text { The patient was seen on the same day as the tooth had fractured. She had com- } \\
\text { plained that the tooth was sensitive to hot and cold after it had fractured but it } \\
\text { was comfortable after the dressing (she was able to use the mouthwash without } \\
\text { any discomfort). The patient was given an appointment before she went away on } \\
\text { holiday. The patient was happy. }\end{array}$ \\
\hline $\begin{array}{l}\text { 4. What didn't } \\
\text { go well? }\end{array}$ & $\begin{array}{l}\text { Pressure was placed on the receptionist and the dentist to 'squeeze' the patient } \\
\text { in between other appointments for the final restoration. This reduced the time } \\
\text { allocated to the other patients and also gave less time than was desired for the } \\
\text { final restoration of the fractured tooth. }\end{array}$ \\
\hline $\begin{array}{l}\text { 5. How might } \\
\text { things have } \\
\text { been done } \\
\text { differently? }\end{array}$ & $\begin{array}{l}\text { The receptionist and dentist could have stood firm. The patient could have been } \\
\text { reassured that the dressing would be alright, and the restoration appointment } \\
\text { made in six weeks. More time could be made in the appointment book for emer- } \\
\text { gency follow up appointments. }\end{array}$ \\
\hline \multicolumn{2}{|l|}{ Action } \\
\hline $\begin{array}{l}\text { 1. Areas of } \\
\text { improvement }\end{array}$ & $\begin{array}{l}\text { Need to rearrange appointment book to allow more time for unscheduled treat- } \\
\text { ments. Need to improve the teams communication skills in order to explain waiting } \\
\text { times and treatment priorities to patients. } \\
\text { Need to prevent the 'treadmill' creeping back into practice. }\end{array}$ \\
\hline $\begin{array}{l}\text { 2. Educational } \\
\text { Needs identified }\end{array}$ & $\begin{array}{l}\text { Time management } \\
\text { Communication skills }\end{array}$ \\
\hline $\begin{array}{l}\text { 3. Which areas will } \\
\text { I address and } \\
\text { in which order- } \\
\text { Will educational } \\
\text { needs be added } \\
\text { to PDP? }\end{array}$ & $\begin{array}{l}1 \text { Time management- this requires action but does not need entry into a PDP } \\
2 \text { Communication skills- to be added to PDP }\end{array}$ \\
\hline $\begin{array}{l}\text { 4. How will I } \\
\text { improve these } \\
\text { areas and meet } \\
\text { those educa- } \\
\text { tional needs? }\end{array}$ & $\begin{array}{l}\text { 1.Time management- As well as the existing emergency slots available each day } \\
\text { (marked with a red highlighter) two 'broken tooth' appointments will be added } \\
\text { to each day (marked with a green highlighter). The red slots can only be booked } \\
24 \text { hours before the appointment time, but the green 'broken tooth slots can be } \\
\text { used seven days beforehand. This will mean that the waiting list for regular and } \\
\text { none urgent treatments might increase slightly but the pressure will reduce on the } \\
\text { receptionist and the dentist as they will have the ability to offer quicker appoint- } \\
\text { ments to those patients who need them. } \\
\text { 2. Communication skills- At the next staff meeting we will discuss the problem. We } \\
\text { will use role play to get all staff to practice communication skills. Although this } \\
\text { situation did not involve an angry or aggressive patient. A course on handling such } \\
\text { patients might give many tips on general patient communication. }\end{array}$ \\
\hline $\begin{array}{l}5 \text { How will I } \\
\text { be able to } \\
\text { demonstrate } \\
\text { improvement? }\end{array}$ & $\begin{array}{l}\text { 1. A white board will be placed in the staff room. Every Monday morning the } \\
\text { receptionist will note down the waiting time for the next } 1 \text {. Emergency appoint- } \\
\text { ment. 2. 'Broken tooth' appointment } 3 \text {. Recall appointment } 4 \text {. Regular treatment } \\
\text { appointment. 5. } 1 / 2 \text { hour treatment appointment. At the end of the week these } \\
\text { figures will be entered into the 'waiting times log'. The waiting times log will be } \\
\text { reviewed at each practice meeting. } \\
\text { 2. An improvement in communication skills is more subjective. If we feel more } \\
\text { comfortable explaining these issues with patients and the patients respond well } \\
\text { then we could say that are communication skills have improved. }\end{array}$ \\
\hline
\end{tabular}

a Significant Events Library, a document that has been circulated to all Sheffield GDPs, postgraduate dental tutors, members of the PCTs involved in dentistry and the Director of Dental Public Health for Sheffield.

The events collected fell into three main themes: incidents that involved clinical treatment, incidents related to the running of the practice and those related to the relationships between members of the team, and members of the team and patients. Consequently the SE Library has been divided into three main categories to aid reference: Clinical, Management and Communication. Each category is then subdivided into sub-categories eg Clinical - Emergencies, Clinical - Endodontics (see Table 2 for examples). In addition, an expert opinion was obtained for three topical events so as to give an evidence-based solution or advice on best practice.

\section{DISCUSSION}

The most positive feedback received during the first year of this pilot related to the face-to-face approach offered by the tutor. On the whole, GDPs responded well to the personal contact with a tutor and the one to one, small group method. The GDPs also appreciated the fact that as a result of the meeting they had a written PDP, thus completing another piece of the clinical governance jigsaw.

Whilst researching SEA, in their qualitative study of GP primary care practices, Westcott, Sweeney and Stead found that many personal, professional and corporate benefits were gained from SEA. ${ }^{11}$ Although more work is needed to investigate the benefits of using SEA in general dental practice, it would seem that this is an excellent tool for use in practice.

The SE library enables the sharing of GDPs' experiences, to increase the profile and promote the use of SEA as a tool for improving the quality of patient care within dental practice. In this way, it is possible to learn how to prevent incidents from happening or happening again. ${ }^{12}$ The library contains an SEA report form in its appendix, developed from Personal Development Plans for dentists $;^{1}$ this can be copied and used as a template for SEA discussion in practice meetings and to report events to the tutor. An example of a completed SEA form is provided in Table 3. 
The PCT tutor is a member of a number of local committees and groups. This has created links between the Regional Postgraduate Dental Education Office, the PCTs and other interested bodies. Building links between the Regional Postgraduate Dental Education Office and the Sheffield PCTs has been an important part of the tutor's role; many PCTs are unaware of the existence of such an office. The tutor can highlight the role of the deanery postgraduate office in providing the postgraduate educational activities required by GDPs to complete their PDPs.

It may be the case that the tutor's role of facilitating the writing of PDPs by the dentists is of even greater value when aimed at the poorly performing dentist. These dentists can be identified by the Dental Practice Advisers (DPAs) or through referral by the Practitioner Advice and Support Scheme (PASS).

Some dentists have been referred to the tutor by Dental Practice Advisers (DPAs) and by the Practitioner Advice and Support Scheme (PASS). The tutor has supported each of these dentists to produce their own PDP. This has given structure to their CPD and has also enabled them to build a portfolio of evidence within their PDP that can be used to prove their commitment to CPD.

Another possible source of future referrals could be:

- The Keeping In Touch Scheme (KITS) that helps dentists taking career breaks, for whatever reason, to keep up to date and to fulfil their GDC requirements to stay on or rejoin the Dental Register. For these dentists, a PDP is very important. Whilst taking a career break they still have to meet the GDC's CPD requirements

- The National Clinical Assessment Service (NCAS), which is a division of the National Patient Safety Agency dealing with poorly performing doctors and dentists. The aim of NCAS is to work with the employer, contracting body or-practitioner to clarify concerns and make recommendations to help the practitioner deliver a high-quality and safe service for patients.

It has been reported that in many of the cases involving poorly performing doctors referred to NCAS, the doctors had undertaken CPD, but this did not address the areas in which the doctor was deficient. ${ }^{13}$ Personal development plans should reflect learning needs as well as an individual's particular interests. ${ }^{14}$ In order to help GDPs address their learning needs, a specific link has been established between the PCT Tutor and the Sheffield Postgraduate Dental Tutor who provides the educational activities for GDPs in the Sheffield area. This closes the loop between the educational needs identified by the Sheffield GDPs and the courses then arranged to meet those needs. The fact that the Regional Postgraduate Dental Education Office now has the specific educational needs for almost 50\% of Sheffield GDPs opens up many possibilities for the Sheffield Postgraduate Dental Tutor to tailor courses to GDPs' needs. There is unfortunately a time lag between the PDP being written (to be completed within 12 months) and the time taken to organise courses.

\section{CONCLUSION}

This PCT Tutor post has facilitated the writing of PDPs by Sheffield GDPs and enabled collection of their associated educational needs. This development has enabled GDPs to embrace the learning and sharing ethos of SEA ${ }^{12}$ and incorporate this form of audit into practice. The face-to-face nature of the PCT Tutor role has increased the yield of data collected. It has also increased the number of GDPs with written PDPs (45\% of GDPs compared with a national average of $16 \%) .{ }^{10}$

The educational needs collected during the first year helped the Postgraduate
Office to plan the use of resources to enable practitioners to fulfil these needs. The incorporation of SEA into practice has highlighted further educational needs. In the second year of the pilot, it will be necessary to follow up the single-handed GDPs and GDPs with low CPD who have not responded to the initial contact from the PCT Tutor. In general the low response rate has been a problem. Initial contact rate was good as this included the well-motivated proactive dentists. Including less interested and more time-constrained dentists is more difficult. This might be improved by varying the time, location and type of meetings used. The best results have been achieved through personal contact with the dentist by the tutor on the telephone.

We would like to thank the Sheffield GDPs who contributed significant events and developed PDPs with the PCT Tutor (PDW).

1. Rughani A, Franklin C D, Dixon S H. Personal development plans for dentists. Oxford: Radcliffe Medical Press, 2003.

2. Lifelong learning. London: General Dental Council 2000.

3. Firmstone $V R$, Bullock A D, Fielding A et al. The impact of course attendance on the practice of dentistry. Br Dent J 2004;196: 773-777.

4. Honey P, Mumford A. A manual of learning styles. Maidenhead, 1986.

5. Hofer T P, Kerr E A, Hayward R A. What is an error? Effective Clinical Practice 2000; 3: 261-269.

6. Pringle M, Bradley C, Carmichael C et al. Significant event auditing. London: Royal College of General Practitioners, 1995. Occasional Paper 70.

7. Pringle $M$, Bradley $C$. Significant event auditing: $a$ user guide. Audit Trends 1994; 2: 20-23.

8. Department of Health. An organisation with a memory. London: The Stationery Officer, 2000.

9. www.radcliffe-oxford.com/pdpdentists.

10. General Dental Council. Report on continuing professional development survey: full report. London, 2001.

11. Westcott R, Sweeny G, Stead J. Significant Event Audit in practice: a preliminary study. Family Practice 2000; 17: 173-179.

12. Seven steps to patient safety for primary care; the full reference guide. London: National Patient Safety Agency, 2005

13. Berrow D, Faw L, Jobanputra R. NCAS Evaluation, Research and Development: Analysis of the first 50 NCAS assessment cases. London: National Clinical Assessment Service. National Patient Safety Agency, March 2005

14. Understanding performance difficulties in doctors: an NCAA report. London: National Clinical Assessment Authority, November 2004. 